\title{
Measuring Sustainability of the "Pay as You Go" Public Pension System in the Republic of Macedonia
}

MIROLJUB SHUKAROV *

South East European University

Tetovo, Macedonia

IVANA VELKOVSKA

MARJAN NIKOLO

Center for Economic Analysis

Skopje, Macedonia

\author{
Original Scientific Paper \\ UDK: 369.5(497.7) \\ doi: 10.3935/rsp.v26il.1561 \\ Received: May, 2018.
}

The analysis of the demographical data indicates that currently the main challenge for the sustainability of the pay-as-you-go public pension system in Macedonia is not the aging population. The revenues from contributions as a percentage of total pension system's revenues are decreasing due to low labour activity, low wages and slow job-creation. The larger deficits of the fund call for an analysis and possible reform action. The paper provides simulations under proposed assumptions until 2030. In our simulations, the pension fund starts to generate surpluses after 2025-26. They are higher or lower depending on the policy to be chosen. The sensitivity of the pension system is the highest to the GDP growth, which points to the need to find mechanisms to accelerate growth.

Key words: pay-as-you-go pension system; aging population; sustainability; employment.

\section{INTRODUCTION}

The Pension and Disability Insurance Fund (PDIF) (the pay-as-you-go public pension system) is experiencing significant current deficits as a result of the growth of pension costs against the lower income from contributions collected from the pension contributors. The major challenge for the pension system in Macedonia is to maintain the relative level of pensioners' living standards, considering the increase in the number of pensioners, the high unemployment and the low wages. This paper provides an analysis of the underlying factors that influence the sustainability of the first pillar pay-as-you-go public pension system. The data used in this paper are from the databases of the State Statistical Office, the Pension and Disability Insurance Fund of Macedonia and the World Bank Database. All methodological techniques used in this paper are explained in detail in the papers outlined in the litera-

\footnotetext{
* Miroljub Shukarov, Faculty of Business and Economics, South East European University, Ilinden b.b. Campus buld. 301, 1200 Tetovo, Macedonia,m.shukarov@seeu.edu.mk
} 
ture and this paper does not refer to their detailed explanation.

According to some authors (Tuffs \& Fairbanks, 2011), that most of the national pension funds are based on principle of solidarity of recent employees and their contributions (pay-as-you-go). The scheme "payas-you-go" has a social logic, and the government is always guarantor for the future payments if the fund cannot provide sufficient amounts from the investment earnings (Connon \& Tanks, 2012). That is the logic for the mandatory public pension systems (schemes). However, pension funds have to be monitored permanently by the internal and external expert bodies and the reports about the fund's financial health should be publicly presented. Especially if there are a lot of adverse or disturbing information and rumours spreading around. Accurate information should be delivered to the public, followed by a government program for managing the risks, even if the risks are of long-term nature (Stewart, 2010).

In the early 1980's, Chile introduced specific pension reform based on advices given by the national and World Bank experts (World Bank, 1994). But after twenty to thirty years it has become obvious that the fund did not delivered expected pensions. Santoro (2017) argues that pensions created social problems to retired people and that system could be good example for poorly designed pension system. In 1981 Chile moved away from a badly-designed set of diverse defined-benefit plans (Soto, 2007) and put in place a mandatory fully-funded defined-contribution plan in the formal sector, with a guaranteed minimum for workers with at least 20 years of contributions. This plan in modified form was adopted by many other countries like Peru, Argentina, Colombia, Uruguay, Bolivia, Mexico, El Salvador, Ecuador, Costa Rica, Panama, and in several Eastern European countries like, Macedonia, Hungary, Po- land, Latvia, Bulgaria, Estonia, Slovakia, Romania etc. According to Barr and Diamond (2016u: 5) in reality this project did not turn out as well as expected due to "low coverage, low pensions, high administration costs, high fiscal costs, lack of gender equality, little competition etc."

Macedonia has au mandatory second pillar pension fund run by two operators, regulated by independent regulator and a third pillar voluntary pension pillar. Currently, all contributions from gross salaries are initially paid to the first mandatory pension fund (first pillar), and 6 percent of the paid contributions are regularly transferred to the second mandatory pension pillar. The analysis of the second pillar exceeds the research subject of this paper which has the aim of addressing the sustainability of the first pay-as-you-go pension system pillar (further the pension system).

\section{THE CURRENT PENSION SYSTEM}

In 1993 Macedonia has established a financial and administrative autonomy of the pension system (Law on Pension and Disability Insurance, Official Gazette of R. Macedonia no. 80/93, 27. 12. 1993). The pension system is based on the pay-as-yougo principle, which means that the collected revenue from contributions paid by the actual pension contributors would have been directly spent for pension payments to the actual pensioners. The transition from the previous economic and political system was the major reason for the decline in production, closure of many enterprises and increase of the unemployment rate. All these changes in the socio-economic development of the country have been reflected in the pension system.

The reforms started as soon as the end of 1993. In the period after 2000, with the adoption of the new Law on Pension and Disability Insurance, as well as a series of 
amendments, a policy of increasing restrictiveness was introduced in the management of the state pension system. These restrictive measures included an increase in the statutory rate for pension contributions from 18 percent to 20 percent, providing additional funds by transferring 9.18 percent of the collected revenues from excise duties on gasoline to the fund and increasing the retirement age (from 60 and 55 years to 63 and 60 years for men and women respectively). It should be taken into consideration that the restrictiveness of these measures provided effects in the short term in terms of achieving better balance between revenues and expenditure and decreasing the inflow of new pensioners and budget transfers to the Pension and Disability Insurance Fund.

The current structure of the multi-pillar pension system is based on the three pillars of pension insurance:

- The pension and disability insurance based on the pay-as-you-go system (first pillar);

- The Mandatory Fully Funded Pension Insurance (second pillar);

- The Voluntary Fully Funded Pension Insurance (third pillar).

The second pillar was introduced in 2002 with Act no. 29, dated 24. 04. 2002 and implemented in 2006. This reform involved an introduction of a fund for mandatory fully funded pension and disability insurance where 6 percent of the paid contributions in the first pillar are transferred.

In 2008 the third pillar, i.e. the voluntary pension funds, started to operate, licensed by the above mentioned agency. The sole activity of the second and third pillar is investing assets in accordance with the investment principles regulated with the Law on Mandatory Fully Funded Pension Insurance and the Law on Voluntary Fully Funded Pension Insurance, in order to maximize return of the investment, exclusively for the benefit of the pension funds' members. It should be noted that the second and third pillar are managed by licensed pension insurance companies that are obliged to obtain a license from the Agency for Supervision of Fully Funded Pension Insurance. According to the agen$\mathrm{cy}$, the reform in pension drives long-term advantages for individuals participating in thu pension system, for the pension system itself, as well as in oversight effects for the system in general.

Studies from other countries from the region suggest that "high unemployment and low level of economic activity contribute to budgetary pressures in the short and medium term, for the public pension scheme as well as for public finances in general" (Werding and Primorac, 2018: 11) a challenge that needs to be addressed through further pension reforms. The sustainability of the Macedonian pension fund on long-run needs to be addressed, analysed and reported in a proper way.

\section{DEMOGRAPHIC TENDENCIES - THE BIGGEST CHALLENGE?}

The age structure of the population has undergone major changes in the last few decades, both in developed and developing countries. The share of the old population in the total population is continuously growing. This trend of population aging is generally more noticeable in developed countries than in developing countries.

In the last ten years, the number of new born in Macedonia has been decreasing resulting in decline of the natural increase by 36 percent from 2005 to 2016 . In economic terms, this means that there would be a reduction in the potential supply of the labour market in the future. On the other hand, for the same time period, the number of deceased people was relatively stagnating, which may imply additional pressure 
on the pension system in the long run. The largest decrease in the number of the population is in Ohrid (-7.15 percent), Bitola (-2.54 percent) and Prilep (-1.94 percent), while the largest increase in the number of people in the last 11 years is in the northern part of the country i.e. in Skopje (5.44 percent), Tetovo (4.62 percent) and Kumanovo (3.05 percent). However, if we compare the data on the number of the people over 65 years as percentage of the total population in Macedonia with the official data of other countries, it can be concluded that currently Macedonia is not facing a serious problem of aging population. (with the exception of Albania before 2014). Between 2005 and 2015, the average life expectancy in Macedonia increased by 1.6 years. Compared to the data for developed countries and countries in the region, Macedonia has the lowest expected average lifespan (with the exception of Bulgaria).

Since the 1960s to the present, there has been a decline in the fertility rate from 4.1 to 1.5 , however there is a stagnation of the fertility rate in the last decade. The lower fertility rate also means that there is a tendency for decrease of the labour supply in the future. The Government of the Republic of Macedonia through a series of policies

Graph 1

Population older than 65 years (\% of total population)

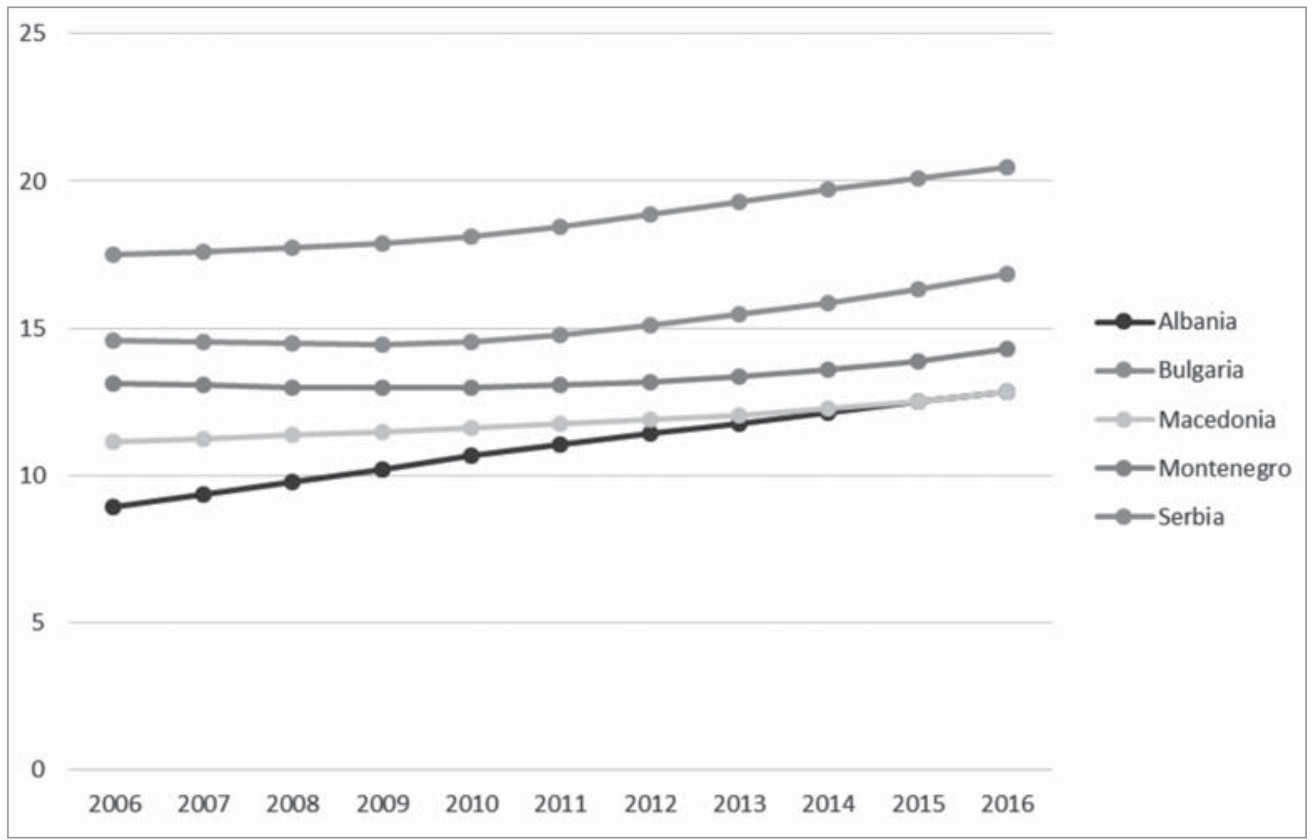

Source: State Statistical Office, World Bank Database.

Namely, Macedonia is not only in a more favourable position compared to developed countries, but also compared to countries from the region (Graph 1) i.e. Macedonia has the lowest percentage of old population tried to affect the fertility rate, which lead to increased public spending. However, even if these policies reach their goal, there is no analysis of whether this change will bring enough new pension contributors and 
revenue from contributions that justify the public spending for this purpose.

The dependency ratio refers to the population below 15 years of age and over 65 years in relation to the number of people aged 15 to 65 years. The fall in the young-age-dependency ratio (as a consequence of the decline in the fertility rate and the number of young people) causes a decline in the overall dependency ratio. In 2006, the dependency ratio was 41 percent, while in 2016 there is a mild downward trend to 40 percent. The old-age-dependency ratio in the last 10 years has been increased by 3 percent, while the dependency ratio of young people has decreased by 4 percent. This may lead to increasing the total amount of pension payments from the fund, while the number of potential future pension contributors could be expected to decline.

Although with a slow pace, the growth of the employment rate contributes to the growth of the number of pension contributors, which also means that the number of pensioners is expected to grow adequately in the future as a consequence of this trend.
The constant increase in the number of pensioners for the analysed period (Graph 2) implies increased spending from the fund in order to provide regular pension payments. Due to the decline in the income from contributions, the deficit in the Pension and Disability Insurance Fund is regularly financed from budget transfers in increasing amounts.

Another important indicator for the sustainability of the pension system is the ratio of contributors to pensioners. In Macedonia, this indicator has increased from 3 in 1991 to 1.7 in 1997, 1.3 in 2003 and 1.9 in 2016. This means that in 1991, 3 pension contributors supported one pensioner. Compared to 1991 the value of the ratio of contributors to pensioners has decreased but lately this ratio has a tendency to increase again. This indicator recorded the lowest value in 2003 when 1.3 pension contributors supported one pensioner. Since then it has shown an increasing trend. These trends in the contributors to pensioners ratio are a consequence of the increased number of pensioners in the last 25 years on the one

Graph 2

Number of contributors and pensioners

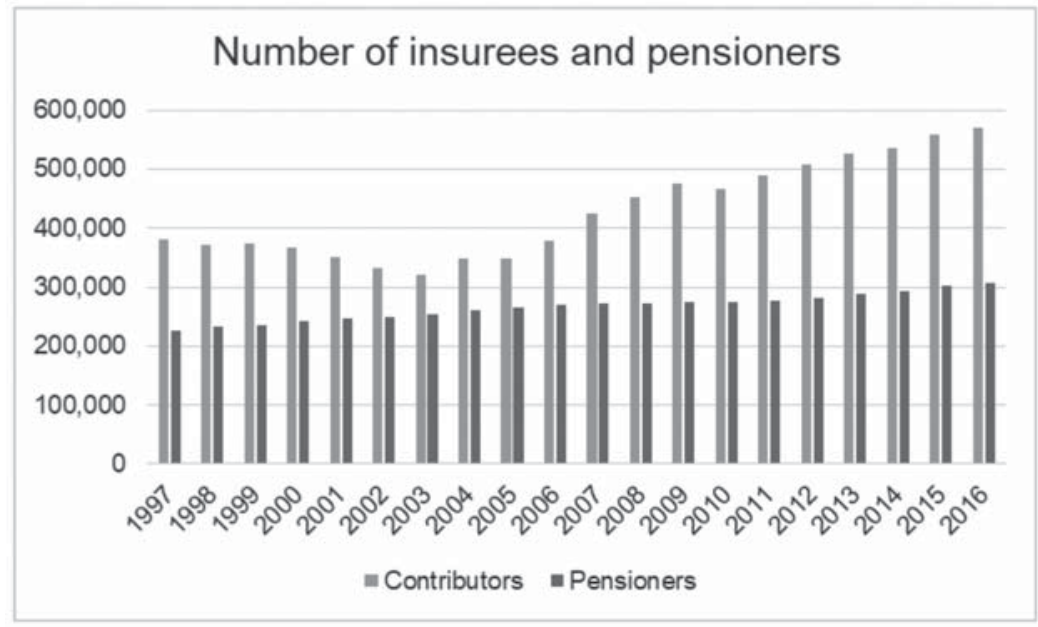

Source: Annual Report PDIF (2016), http://www.piom.com.mk/statistika/. 
hand and the slow creation of new jobs, especially outside of the labour-intensive low-paid jobs on the other hand.

During the transition period i.e. early 1990 s, the average pension was growing in its absolute value, but it has also increased relative to wages. The ratio of the average monthly pension as a percentage of the average monthly net salary is an important indicator of the sustainability of the pension system. This indicator decreased by 3.2 percentage points (i.e. from 61.5 percent to 58.2 percent) from 2001 to 2015 , although since 2010 when it recorded its lowest value of 47.9 percent, the indicator has increased by almost 11 percentage points. Lower values of the indicator would mean that the level of salaries that generate revenue from contributions to the fund will more easily cover the cost for pensions. On the other hand, when pensions do not grow at the same pace with monthly salaries and 65 percent of the total tax revenues are collected from consumer taxes that equally affect all citizens, regardless of their ability to pay, it turns out that the effect of the gap in the growth of monthly salaries and pensions in Macedonia increases the inequality and vulnerability of the pensioners as a social category.

Until 2000, the Macedonian pension system was publicly funded based solely on the principle of intergenerational solidarity. The financial dificulties related to payment of pensions and the demographic trends have intensified the need to reform the pension system. The costs of pensions and the number of pensioners were continuously increasing, while the sustainability of the fund's revenues was jeopardized due to the unemployment problem, low wages and reduction of the statutory rate for pension contribution (from 19 percent to 18 percent since 2010). The latest data available in the annual reports of the Pension and Disability Insurance Fund show that in the last 10 years, the amount of pension expenditures increased by 90 percent, while the remaining costs of the Pension and Disability Insurance Fund increased by 126 percent. However, this increase is not so concerning given the fact that the percentage of the cost of pensions is as much as 78 percent of the total expenses of PIOM. The pension expenditure in total expenditure declined by only 2 percent in the last 10 years. In any case, the increase in the non-pension fund costs should be limited in order to improve the sustainability of the pension fund. On the revenue side, it can be concluded that the share of the contributions from pension and disability insurance to total revenues of the fund are declining, i.e. from 61 percent in 2006 to 54 percent in 2016, a decrease of 7 percentage points. On the other hand, budget transfers of total fund revenues increased by 15 percent, i.e. from 28 percent in 2006 to 43 percent in 2016. It should be taken into consideration that revenues from pension contributions are decreasing although the number of pension contributors is growing. One of the reasons for this is the reduction of the statutory pension contribution rate, but even bigger reason is the fact that the majority of the employees have very low salaries.

Although the employment rate and the amount of average monthly net wage are rising (Graph 3), it can be claimed that these data do not reflect the realistic picture of the employed in the Macedonian economy. Macedonia is a country with big income inequalities and although there is an increase in the average montly wage, this growth is mainly due to the increase of the income of only few percent of the richest groups of citizens, while the majority of the population have low wages that directly affect the low payments from contributions to the fund. As a consequence, central budget transfers are rising in order to cover the increased fund deficit. 
Graph 3

Average Net Wages in Macedonia 2005-2017 (EUR)

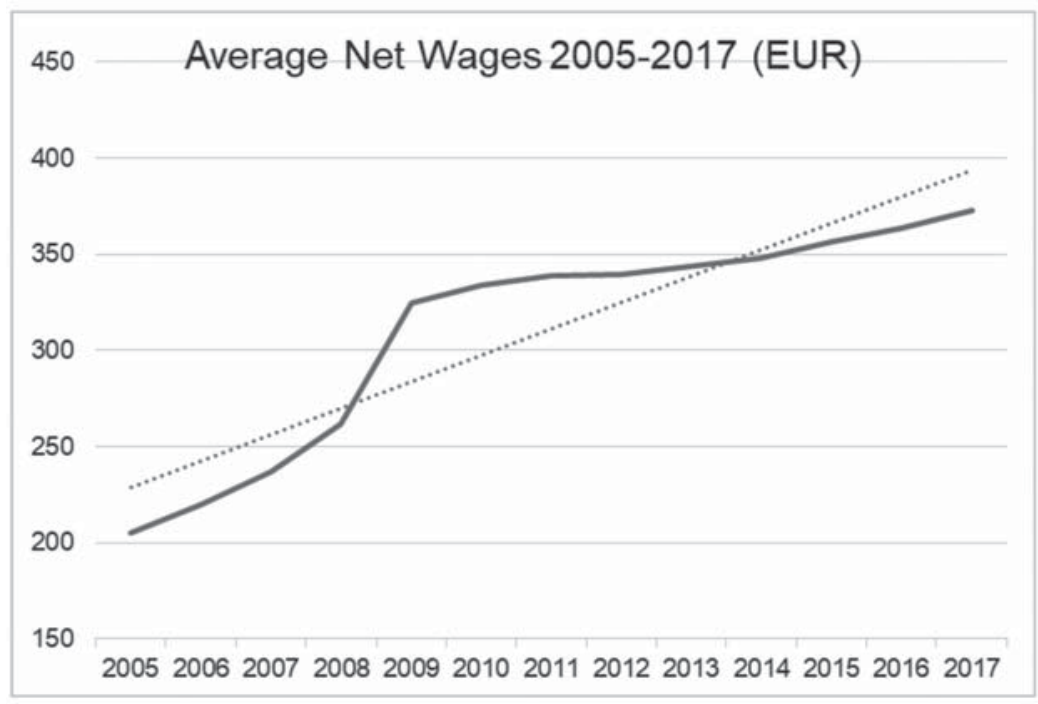

Source: State Statistical Office Macedonia, wwwt.stat.gov.mk.

\section{EFFECTS OF INCREASED EMPLOYMENT ON THE SUSTAINABILITY OF THE FIRST PENSION PILLAR}

As mentioned in the text above, although the country's population is getting older, at the moment this trend is not alarming compared to the data from developed countries or other countries in the region. Therefore, currently population aging should not be identified as the main challenge for the sustainability of the Macedonian pension system. Even though aging population may impose a challenge in the future, policy makers should have in mind that currently the main problem that threatens the sustainability of the pension system in Macedonia is the high level of unemployment, low salaries and thus the insufficient revenues from pension contributions in the pension fund.

Although unemployment is decreasing and the number of pension contributors is rising, the amount of revenues from pension contributions as a percentage of total fund revenues has declined, partly due to the decrease in the statutory contribution rate, but much more as a result of high unemployment and low wages. This is why in order to reduce the fund's deficit there should be an increase in employment, however not only in the labor-intensive low-paying occupations. Attracting and establishing companies that offer high-paid jobs is a long lasting process and requires long-term investment in high value-added industries. In the medium term, improving the sustainability of the pension system in Macedonia would involve creating a favorable environment for rise of employment by the current market players. For this purpose, the paper analyses the effect of employment growth, i.e. the effect from growth in the number of pension contributors on the current deficit (other conditions remaining the same). It should be noted that in both scenarios, only the number of pension contributors is changed due to employment growth and all other conditions remain the same. For ex- 
ample, the potential changes in wages are not taken into account. Growth of average wages requires long-term reforms related primarily to education, attracting foreign direct investment from high value-added industries, and private sector development. It is important to note that these projections also mean that the statutory contribution rate for pension and disability insurance should freeze at 18 percent, i.e. its predicted decrease of 17.6 percent in July 2018 should be amended as a measure to increase the sustainability of the pension system.

We analysed the following two scenarios for the period from 2017 to 2022, based on the latest available data for 2016:

1. Scenario 1 - employment growth of 6.2 percent per year in the next six years (twice as much the current employment growth);

2. Scenario 2 - employment growth of 3.1 percent per year in the next six years (which is the average growth rate in the last five years)
If we make a simulation when employment starts to grow by a twice faster pace than the current one, and if all the other conditions remain the same, the need for funds to be transferred from the state budget for covering the current fund deficit would be constantly reduced and in 2022 they would be no longer needed (Graph 3).

In the second scenario of the analysis, a growth of 3.1 percent per annum is predicted, which is the average growth of the number of employees/pension contributors in the last 5 years. This way the current deficit will potentially be halved in the next six years, not taking into account the growth of average wages and only if all other conditions remain the same (the potential increase in the number of pensioners and other non-pension fund costs are not taken into account). It can be claimed that under these conditions an improvement in the sustainability of the Pension and Disability Insurance Fund should be expected in the medium term (the next six years).

Graph 4

Projection of the fund deficit (in MKD)

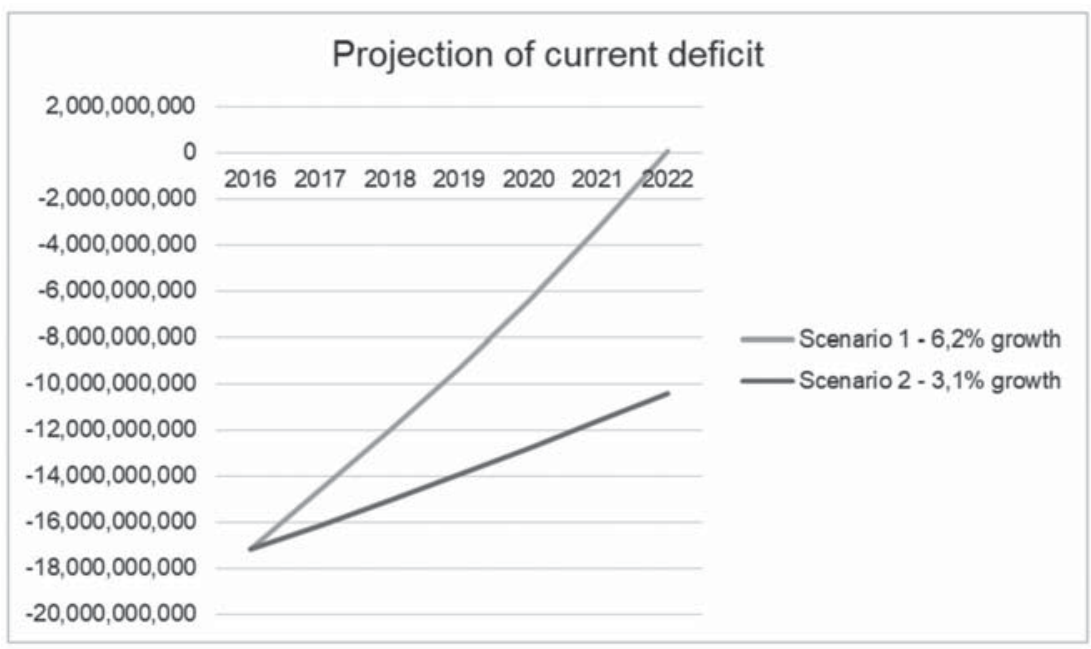

Source: State Statistical Office, Annual Report PDIF (2016), own calculations. 


\section{Simulations of different policies on the sustainability of the pension system}

It should be expected that the pressure of the PDIF will be gradually reduced after 2020, and this should continue until 2023. The assumption that we are introducing is that in 2006 the average age of the pension contributors is 44 years that had in average 15 years of retirement span. To assume a lower age would be unjustified from the aspect of the introduction of the second fully funded pension pillar. Having these assumptions in mind we can say that in 2017, the minimum length of retirement service is about 26 years, and the minimum age is about 56 years. Until the retirement of the last pension contributor/employee it would take 8 years or everyone would retire by the year 2025. However, the average age of retirees should be around 69 years. The rate of mortality to be used will correspond to the mortality tables by age groups of the population at intervals of $60-69 ; 70-79 ; 80$ 89 and $90+$. The simulation analysis is done by 2035 , when it is expected that the entire contingent of pension contributors in the first pillar will become pensioners and for the period that follows, solutions that will make the pension system sustainable should be identified and applied.

We should also consider that the current statutory retirement age is 64 years (62 years for women) or 67 (given the possibility to extend employment) and the average life expectancy is 75 years (for men around 72 years and for women 76 years). This means that on average every pensioner will receive his (retirement) pension for 11-12 years. However, a precise analysis require availability of data on the mortality rate by age groups. These data are used in the following simulations.

On the other hand, considering the employment in the Technological Industrial Development Zones (TIDZ), an outflow from the budget corresponding to the payments in the second pillar must also be taken into consideration. There is no accurate data on the number of employees in the TIDZ and the amount of wages, as well as individual arrangements with the government agencies, so these effects are not analysed here, but we have made our own assumptions that are entered in the simulations. The basic motive for this is that the measures for encouraging employment in TIDZs are contracts that stipulate temporary release from the obligation to pay the contributions for pension insurance. That obligation is taken over by the budget of the Republic of Macedonia.

It should be noted that the growth of gross wages is not calculated as a generator of final consumption, for which a more complex model based on the multiplier effect should be developed. The simulations presented in this section are based the following assumptions:

The first is that at the moment of introducing the second pillar, employees who pay contributions to the mandatory pension fund have at least half the statutory required period for retirement (15 years). At that time it would take 20 years to retire (they had an average of 44 years). The logic is that if they had a shorter retirement service they would have been candidates for the second pension pillar.

Secondly, today in 2017, ten years after the cut-off date, a large proportion of those pensioners have already exercised their right to retire, and the last contingent of pensioners would take another 8-10 years to retire. Today's age structure of pension contributors suggests that in the next few years the number of pensioners will grow with the current average dynamics of 5,500 to 6,500 pensioners per year. Then the inflow of new pensioners will start to decline sharply.

Thirdly, the average life expectancy in Macedonia is about 75 years. This means 
that the period of payment of pensions will be extended by 10-15 percent.

Fourthly, the average adjustment of pensions is expected to continue to grow at an annual rate of 3 percent (as before, and not 5 percent as declared). Of course, if the correction of pensions is made with the cost of living, the whole calculation should undergo significant changes, especially in the long run.

Fifthly, the average salary that represents a base for pension contributions remains to grow at the same rate as in the past few years.

Sixthly, the ratio of wages to pensions is changing year by year. The simulation attempts to keep the ratio stable at the level of 59-61 percent. So, in this analysis an attempt will be made to simulate the financial position of the pension fund in the coming years, and in particular the period until 2025 will be elaborated.

\section{Zero option: What happens if} everything remains the same

The continuation of the same trends suggests that if the length of the retirement service remains unchanged, by 2023 the allocation of funds to PDIF should increase from the current 10.2 percent to 14.1 percent of the budget, the share of total pensions in GDP would decrease from the current 9.8 percent to 7.1 percent, and the budget participation to GDP would be 5.3 percent. This would not significantly change even if the retirement age is increased. In 2025 the budget participation would be around 2.3 percent of GDP, and the total paid pensions would amount to 7.7 percent of GDP. However, about 6.6 percent (of the current 13.8 percent) of the budget would be transferred to the pension fund.

Graph 5

Zero option: What happens if everything remains the same

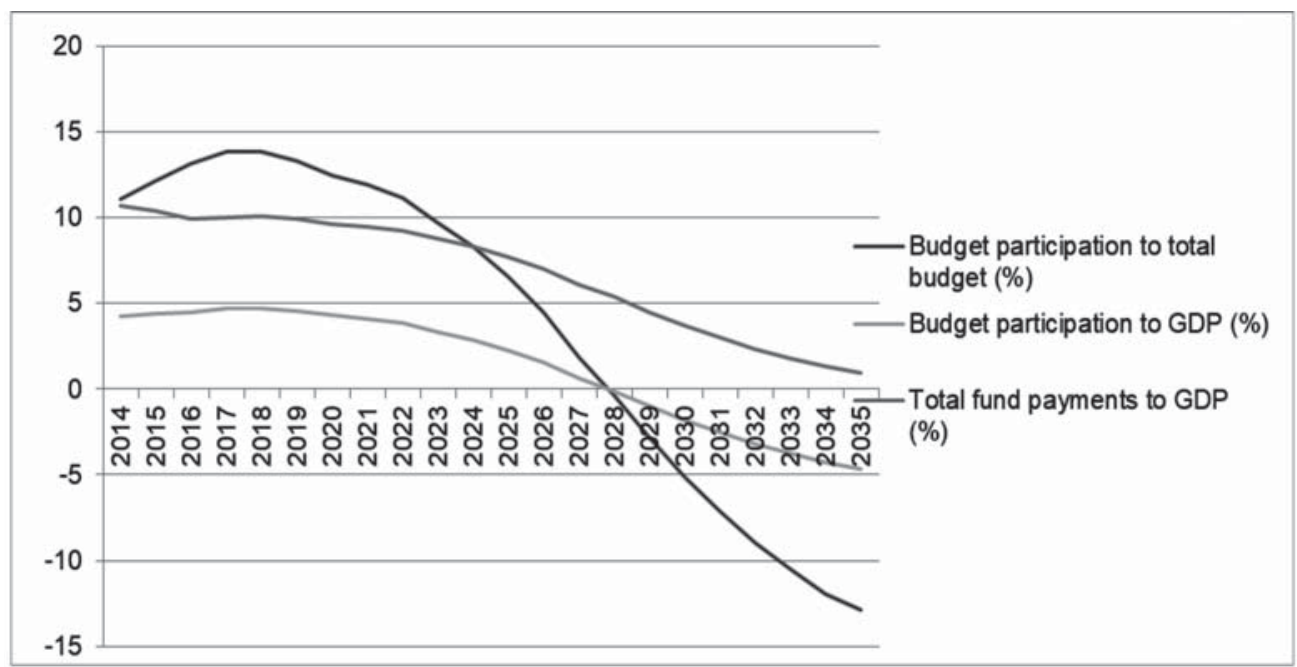

Source: State Statistical Office, own calculations (2016). 
Projection of the impact of increased salaries on the change in revenues in the pension fund

If we apply a dynamic simulation where gross wages and GDP would grow at rates that correspond to a small and poor economy like Macedonia (rates of 5-6 percent per year) then the situation is changing significantly. Namely, even with unchanged retirement age with a rise in gross wages in 2017 by 5 percent, and if the budget is expected to grow at rates of 3 percent per year, budget allocation will be reduced to 6.0 percent, and the share of total pension payments to GDP will be around 7.2 percent, and the budget participation for pensions would be around 1.7 percent.

\section{Projection of the impact of increased} rate for contributions from 18 percent to 20 percent on the change in revenues in the pension fund

This simulation is adding increased pension contributions rate from 18 percent to
20 percent to the previous dynamic simulation. In this case the budget participation for the pension fund in 2025 would represent 4.2 percent of the budget, would participate in GDP with 1.4 percent, and the total pension payments would account for 7.2 percent of GDP.

Each of the simulations shows that in the long run the pension system in Macedonia is sustainable (2030). That is, the pension fund starts to generate surpluses after 2025-26. They are higher or lower depending on the policy to be chosen. The most positive effects come from the simulations that suggest GDP growth of 5 percent annually, which points to the need to find mechanisms to accelerate growth. It is a particularly important issue to immediately intiate reform of the Pension Fund, i.e. to determine in which direction it will be transformed at the moment when it starts to create surpluses.

According to the simulations, if nothing changes, the pension fund will already generate a surplus of minimum 130 million

Graph 6

Projection of the impact of increased salaries on the change in revenues in the pension fund

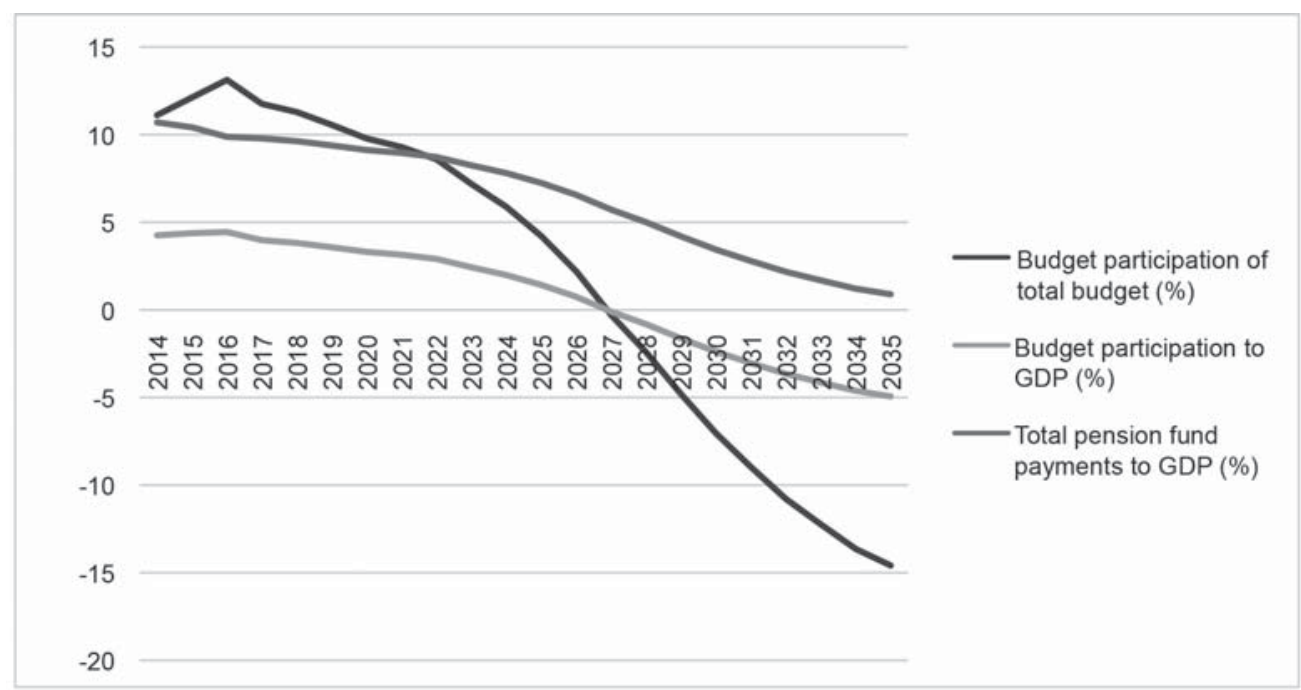

Source: State Statistical Office, own calculations (2016). 
euros in 2030, but if there is a relatively higher growth, the surplus could exceed 1.5 billion euros cumulatively for the period. Policy makers should decide whether to increase the transfers to the second pillar, to privatize the first pillar or to rebuild the first pillar into an investment fund for support of growth, innovation and creation of new employment.

Table 1

Results from simulations (in million euros)

\begin{tabular}{lccc}
\hline \multicolumn{3}{c}{ Pension policy } & Net effect \\
$\begin{array}{l}\text { Retirement } \\
\text { age (male } \\
\text { workers) }\end{array}$ & Growth & $\begin{array}{c}\text { Increase of } \\
\text { contribution } \\
\text { rate }\end{array}$ & $\begin{array}{c}\text { (in } \\
\text { million EUR) }\end{array}$ \\
\hline 67 years & yes & yes & 3800 \\
\hline 64 years & yes & yes & 3700 \\
\hline 64 years & yes & no & 1850 \\
\hline 67 years & yes & no & 1800 \\
\hline 61 years & yes & no & 570 \\
\hline 67 years & no & yes & 241 \\
\hline 64 years & no & yes & -90 \\
\hline 61 years & no & yes & -890 \\
\hline 67 years & no & no & $(1220)$ \\
\hline 64 years & no & no & $(1445)$ \\
\hline 61 years & no & no & $(2400)$ \\
\hline
\end{tabular}

Source: State Statistical Office (2016), own calculations.

\section{CONCLUSIONS}

Currently, the deficit of the PDIF is not increasing due to unfavorable demographic tendencies as much as it is caused by systemic problems. The process of generating new jobs is slow and the amount of contributions is relatively low. In the medium term, Macedonia is not facing population aging as much as other countries, which means that rising the age limit for pension allowance is not an appropriate measure to tackle the problem of sustainability of the pension system in Macedonia.
Macedonia has a problem with unemployment, low rate of job creation and low wages. This causes a decline in the amount of collected revenues in the pension fund as percentage of total revenues in the fund because unemployment, slow job-creation and low wages are directly linked to the number of pension contributors and the salary levels. According to the current legislation the statutory rate for pension contributions is going to decrease from 18 percent to 17.6 percent starting July 2018. It is necessary to evaluate the existing policies that foresee a reduction in the rate of contributions for pension and disability insurance, whose goals to increase both the employment and the wages in Macedonia have not been achieved but have only caused lower revenue in the pension fund. On the other hand, a removal or a more drastic increase (since January 2018 there has been an increase of 2 average monthly salaries) of the ceiling for the tax base for pension contributions should be analysed as a possible measure for tackling the problem of sustainability of the pension system as a whole. According to the simulations performed in the calculations for the purpose of this paper, the pension system in Macedonia should not fear unsustainability in the long run due to the fact that after 10 years the first pillar will feel significantly less pressure from pensioners because at that time most of the pensions will be financed by both the first and the second pillar. Having in mind that the private pension funds (the second and third pillar) are generating profits, we should not expect financial difficulties for pension payments in the long run.

\section{REFERENCES}

Barr, N., \& Diamond, P. (2016). Reforming pensions in Chile, Polityka Społeczna, (1), 4-9. Available at https://economics.mit.edu/files/12427

Cannon, E. \& Tanks, I. (2012). The value and risk of defined contribution pension schemes: International evidence. Journal of Risk and In- 
surance, 80(1), 95-119. https://doi.org/10.2139/ ssrn. 1443785

Center for Economic Analysis. (2011). Report on the publicly funded pension scheme in Macedonia. Available at https://cea.org.mk/documents/studii/ CEA_Pension \%20PAYG\%20review.pdf

Economic Policy Committee \& European Commission. (2006). The Impact of ageing on public expenditure. Bruxelles: European Union.

Haberman, S., \& Sibbett, T. A. (Eds.). (1995). History of Actuarial Science. London: Routledge.

Santoro, M. (2017). Pension reform options in Chile: Some tradeoffs. Washington, DC: IMF Western Hemisphere Department.

Soto, M. (2007). The Chilean pension reform: 25 years later. Pensions: An International Journal, 12(2), 98-106. https://doi.org/10.1057/palgrave. pm.5950049
Stewart, F. (2010). Pension funds' risk-management framework: Regulation and supervisory oversight. Paris: OECD Publishing.

Tufts, W., \& Fairbanks, L. (2011). Pension Ponzi: How public sector unions are bankrupting Canada's health care, education and your retirement. Mississauga, ON: Wiley.

Werding, M., \& Primorac, M. (2018). Old-age provision in transition: the case of Croatia. Journal of Pension Economics and Finance, 17(4), 1-18. https://doi.org/10.1017/S1474747217000166

Woelfel, C. J. (1994). The Fitzroy Dearborn Encyclopedia of Bancing and Finance (10th Edition). Chicago: Fitzroy Dearborn Publishers.

World Bank. (1994). Averting the old age crisis : Policies to protect the old and promote growth. Washington, DC: The World Bank. 


\title{
Sažetak \\ MJERENJE ODRŽIVOSTI JAVNOG MIROVINSKOG SUSTAVA TEKUĆE RASPODJELE U REPUBLICI MAKEDONIJI
}

\author{
Miroljub Shukarov \\ South East European University \\ Tetovo, Macedonia \\ Ivana Velkovska \\ Marjan Nikolo \\ Center for Economic Analysis \\ Skopje, Macedonia
}

Analiza demografskih podataka upućuje na to da trenutno glavni izazov za održivost javnog mirovinskog sustava tekuće raspodjele u Makedoniji nije starenje stanovništva. Prihod od doprinosa kao postotak ukupnih prihoda mirovinskog sustava smanjuje se zbog niske radne aktivnosti, niskih plaća i usporenog stvaranja novih radnih mjesta. Veći deficiti mirovinskog fonda zahtijevaju analizu i moguće reformske akcije. U radu se pružaju simulacije prema predloženim pretpostavkama do 2030. godine. U našim simulacijama, mirovinski fond počinje stvarati višak nakon 2025.-'26. godine. Viškovi su veći ili manji, ovisno o mjerama koja treba odabrati. Osjetljivost mirovinskog sustava najviša je u odnosu na rast $B D P-a$, što ukazuje na potrebu pronalaženja mehanizama za ubrzavanje rasta.

Ključne riječi: mirovinski sustav tekuće raspodjele, starenje stanovništva, održivost, zaposlenost. 